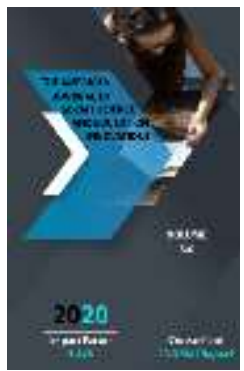

\section{Improving The Effectiveness Of Administrative Sanctions For Violations Of The Established Procedure In The Conduct Of Public Events}

\author{
Khudoyberdiev Abdurashid Abdirasulovich \\ Senior Lecturer At The Department Of Administrative Law Of The Academy Of The Ministry \\ Of Internal Affairs Of The Republic Of Uzbekistan
}

Journal Website: http://usajournalshub.c om/index,php/tajssei

Copyright: Original content from this work may be used under the terms of the creative commons attributes 4.0 licence.

\title{
ABSTRACT
}

The article addresses the issues of improving the Code of Administrative Republik of Uzbekistan for violations of the established rules related to the organization and conduct of public events.

\section{KEYWORDS}

Publik event, public disorder, civil safety, administrative law, public order, petty hooliganism, administrative liability.

\section{INTRODUCTION}

Chapter 15 of the Code of Administrative Responsibility of the Republic of Uzbekistan establishes administrative liability for offenses that violate public order. Such administrative offenses are defined as an violation of state and public order, an unlawful act or omission, and for which liability is provided. The commission of such an offense shall be the sole basis for the imposition of administrative sanctions. The form of guilt is expressed differently in the legal norms establishing liability for violation of public order. In some cases, for example, the biased or extreme nature of the action is directly indicated, while in others the exact form stems from the content of the biased action structure.

Due to the issues raised by the courts on the application of the law on liability for riots and the adoption of new criminal laws, the Plenum of the Supreme Court of the Republic of Uzbekistan adopted a number of decisions[1]. 
According to the decision of the Plenum of the Supreme Court, only organizers and participants of riots can be prosecuted under Article 244 of the Criminal Code if they committed direct massacres, vandalism, arson and other similar acts or armed resistance to the authorities, if a group if the actions of individuals violate public order, but are not accompanied by massacres, vandalism, arson and other similar acts, such actions can not be considered mass riots, if appropriate, will be prosecuted under Article 277 of the CC, if characterized by a complex of crimes committed by participants in mass riots, such as thefts, robberies, raids, and other crimes that constitute a separate crime[2]. Violence against a person must be understood to mean inflicting bodily harm on the victim, as well as any other act that restricts his or her liberty and impedes the exercise of his or her legal rights. A weapon used in the course of a mass riot must be understood to be a firearm, a cold steel weapon, or any other device specially designed or adapted to inflict bodily harm and death on a person. Includes metal chains, cut pipe, fittings and other similar equipment. Individuals who have not committed any criminal act but have been in the crowd during a riot are not criminally liable, but can be prosecuted under Article 201 of the Code of Administrative Offenses for violating the order of holding meetings, rallies, street marches or demonstrations.

Every year, about 20,000 public, political, cultural, national, professional and sports events are held in the country. In total, more than 55 million participants are taking part in these events. One of the administrative and legal problems in ensuring public order and safety by law enforcement agencies and the National Guard during public events is the lack of an administrative code in the current Code of Administrative Responsibility for violating the rules of public order and public safety during public events. Chapter XV of the Code of Administrative Responsibility of the Republic of Uzbekistan for offenses against public order was amended by the Law of the Republic of Uzbekistan "On Amendments and Addenda to the Code of Administrative Responsibility" of April 25, 2003, Article 200 (violation of the rules of public events).

The administrative legal norm of this article is mainly the rules of holding public events in relation to the organizers of public events, ie the rules "On measures to further improve the organization and conduct of public events" approved by the Cabinet of Ministers of the Republic of Uzbekistan dated July 29, 2014 No. 205 applied without fulfilling the requirements. Violations of public order and security are common in the practice of law enforcement agencies, mainly during public events.

These offenses are more socially dangerous than petty hooliganism (Article 183). Because an offense committed during a public event can lead to mass riots or injure many citizens. In practice, offenses of this nature are now classified by law enforcement agencies as petty hooliganism offenses.

According to the legal scholar H.R.Alimov, public order is a system of social relations regulated by moral, legal norms and the rules of morality, etiquette, customs[3]. Public order is protected by state bodies, public associations and citizens. The main role in this work is played by law enforcement agencies.

Minor hooliganism (Article 183), ie insulting with obscene words in public places, insulting citizens, and other similar acts that violate public order and public order-intentional disregard for the rules of conduct in society, lead to administrative liability. Public order is the object of petty hooliganism. Public order is a relationship based on the observance of the rule of law in public places. Public order is 
strengthened not only by legal norms, but also by other social norms, ethics, customs, norms of public organizations[4]. Legal norms play a key role, as they determine the legal liability, type and norm of punishment for a breach of order. The behavior of the perpetrator is a clear disregard for the interests of society, the surrounding citizens, low cultural level, disregard for existing rules of morality and decency.

Behavior that disturbs the peace of citizens and public order characterizes the objective aspect of the offense. These include: swearing in public, insulting citizens, that is, abusive behavior that insults the honor, dignity, and peace of another person. It also includes forcing a citizen into a conversation that insults his human dignity, shaking his hand with a whip or grabbing his hand by force, tearing off his hat; cigarette smoke can be blown into his face and so on. An important sign of the objective side of petty harassment is the situation, space, time. In different contexts, the same behavior has different meanings. For example, swearing in public with obscene language can be described as a petty hooliganism, as well as a criminal act of hooliganism at a meeting, celebration or other public event (Article $277 \S$ 3 of the $(C)$.

According to the legal scholar H. Alimov, petty hooliganism is often carried out in public places, that is, it is based on public perception[5]. However, given that disregard for the community or human dignity becomes apparent, the offense may have been committed in secret.

Minor harassment is characterized by the fact that it is subjectively intentional and often overt. The perpetrator realizes that he is acting against the law, and as a result, allows the consequences - a violation of public order and public order. Minor hooliganism differs from hooliganism under Article 277 of the Criminal Code of the Republic of Uzbekistan. Hooliganism in Chapter XX of the Criminal Code of the Republic of Uzbekistan, ie intentional disregard for the rules of conduct in society, is associated with beatings, minor injuries or significant damage to property or significant destruction of another person. occurs. In order to qualify an act under Article 277 (1) of the Criminal Code, not all of the above consequences must be present at the same time.

Hooliganism is an act of deliberate disrespect for the rules of public order. Based on this legal definition, it should be noted that the behavior of hooliganism is an violation of public order. Public order as an object of aggression means the necessary behavior in the interaction of people, the peace of society and citizens, universally recognized moral, legal, religious, spiritual, national and other traditions and customs, which form the basis of social behavior and rules of conduct. and the set of social relationships that ensure respect and adherence to values must be understood. Hooliganism is manifested in active actions that objectively represent disregard for the rules of morality in society.

Forms of disregard for the rules of morality in society are diverse, as public order can also be disrupted by obscene language, beatings, violence against citizens, destruction or damage to property[6]. But for all acts of hooliganism, it is inherently a violation of the public order, which is legally protected, by disregarding the rules of morality that are accepted by all in society. Ignorance of the rules of morality in society means disrespect for the law, social behavior and morals, generally accepted traditions and customs, the established way of life. A person commits certain actions that constitute public order and harm social relations protected by law or pose 
a real risk of harm, regardless of the rules of morality in society. Usually, the disregard for the rules of morality in society is obvious, that is, it happens in front of most people.

Hooliganism often takes place in public places (theater, park, stadium, street, restaurant, cafe, etc.) where people work and have fun, but hooliganism-type riots and wars often take place in non-public places. In deciding whether such incidents should be considered hooliganism, it is necessary to determine whether there are clear signs of disregard for the rules of public order and the well-being of not only family members but also other citizens. Under current law, there must be a causal link between the offender's actions and the violation of public order. An act without a causal link must be considered a crime against a person or property.

Resolution No. 9 of the Plenum of the Supreme Court of the Republic of Uzbekistan of 14 July 2002 "On Judicial Practice in Cases of Hooliganism" stipulates that courts must distinguish between the crime of hooliganism and an administrative offense of petty hooliganism. The notion of petty hooliganism is defined in Article 183 of the Code of Administrative Offenses of the Republic of Uzbekistan. is manifested in the act of overt disregard for the rules of conduct. In this case, if there are no signs of part 1 of Article 277 of the Criminal Code. It is not possible to qualify under Article 277 (2) (b) of the Criminal Code. An average of 4,100 hooliganism cases and about 60,000 petty hooliganism are detected by law enforcement agencies each year.[7] Hooliganism during public events is characterized by gross disrespect for people and society as a whole, as non-recognition of rules and disrespectful behavior occurs directly during celebrations, ceremonial marches and demonstrations, military parades, festivals and other public events. are given.
Hooliganism during public events is dangerous with the threat of causing mass riots. Paragraph 9 of the Resolution of the Plenum of the Supreme Court of the Republic of Uzbekistan No. 9 of June 14, 2002 "On Judicial Practice in Cases of Hooliganism" defines "public event" as follows: "... in the prescribed manner, public authorities, public associations, as well as official events, celebrations, demonstrations, rallies, meetings, elections, public clearings organized by the selfgoverning bodies"[8]. understood. Hooliganism committed during the abovementioned public event may be qualified by Article 277 (3) (c) of the Criminal Code.

In our opinion, both the decision of the Plenum of the Supreme Court and the current Criminal Code (Article 277) and the Code of Administrative Liability (Article 183) do not fully legalize actions related to criminal misconduct during a public event.

First, public events do not include concerts, sports and a number of other public events that are not held by government agencies. In many cases, in practice, there are violations of public order during these events.

Secondly, if the acts provided for in the above legislation in the offense of petty hooliganism (Article 183) are committed during a public event, it would not be appropriate to qualify this hooliganism as a crime under Article 277 (3) (c). This contradicts the principles of liberalization of criminal penalties in our country.

Based on the analysis of the above-mentioned scientific considerations, Article 2002 of the Code of Administrative Responsibility of the Republic of Uzbekistan. Violation of the rules of maintaining public order and ensuring the safety of citizens during public events. 
The introduction of this article in the administrative legislation will legally systematize the actions of law enforcement agencies and the National Guard to ensure public order and safety during public events, and will prevent criminal prosecution of offenders for these actions.

Taking into account the problematic situations in the above administrative legislation and the practical activities of law enforcement agencies, it is expedient to state Article 202 of the Code of Administrative Responsibility of the Republic of Uzbekistan in the following wording:

\section{Article 202. Creating conditions for unauthorized public events}

Provision of premises or other property (vehicles and communications, printing and other technical equipment) to the organizers and participants of unauthorized public events or other conditions for such events - from fifty to one hundred times the basic calculation for citizens, and for officials - seventy shall be punishable by a fine of one hundred and fifty times the amount of the fine.

\section{REFERENCES}

1. Decision No. 9 of the Plenum of the Supreme Court of the Republic of Uzbekistan of June 14, 2002 "On Judicial Practice in Cases of Hooliganism" // National Database of Legislation. www.lex.uz.

2. Decision No. 9 of the Plenum of the Supreme Court of the Republic of Uzbekistan of June 14, 2002 "On Judicial Practice in Cases of Hooliganism" // National Database of Legislation. www.lex.uz.

3. Alimov H.R., Mahmudov A.A., Ismailov N.T., Administrative law. T., Academy of the
Ministry of Internal Affairs of the Republic of Uzbekistan, 2003. - B. 91-117.

4. Administrative activity of internal organs. Chast obshchaya // Pod red. A.P. Koreneva. - M., 1997; Administrative activity of internal organs. Chast osobennaya // Pod red. A.P. Koreneva. MYul MVD Rossii. «shchit-M», 1997.

5. Alimov H.R., Mahmudov A.A., Ismailov N.T., Administrative law. T., Academy of the Ministry of Internal Affairs of the Republic of Uzbekistan, 2003. - B. 91-117.

6. Selimanova S.M. Administrative law. Textbook. - T., -2019. - $657 \mathrm{~s}$.

7. Statistics of PPX and JTSBB of the Ministry of Internal Affairs of the Republic of Uzbekistan for 2015-2019.

8. Decision No. 9 of the Plenum of the Supreme Court of the Republic of Uzbekistan of June 14, 2002 "On Judicial Practice in Cases of Hooliganism" // National Database of Legislation. www.lex.uz. 